\title{
Colors and their artistic image creation features
}

\author{
Avulova Nargiza Toxirovna ${ }^{1}$ \\ ${ }^{1}$ Doctoral student of the Tajik language and literature department of Samarkand State University \\ E-mail: Nargiza.avulova18. @mail.ru phon: +998912280880
}

\begin{abstract}
Colors have long been used by artists as a means of depicting unique and beautiful landscapes, to ensure the attractiveness of speech, to create an artistic image in poetry. The colors are used in works of art, mainly in lyrical genres, reveals the appearance of inner experiences, emotions, beauty and creative influence. In poetry, such forms of art as allegory, allegory and irony are expressed through colors.Classical and modern Persian-Tajik poets skillfully used the means of color in their work, creating beautiful and unique images through their artistic potential. Nowadays, in Tajik literature, the properties of colors to create an artistic image have not been fully studied. This article describes the features of colors in lyric art and their role in poetry on the basis of concrete evidence from the poems of new Tajik poets.
\end{abstract}

Keywords: color, description, image, spirit, content, emotion.

\section{INTRODUCTION}

In new literature, there is a growing interest in the unexplored aspects of classical and new literature. In particular, the tendency to study the issue of the poet's artistic image and creative skills in this process is one of them. At the same time, the use of different colors in the poetry of classical poets, their content and specific aspects, as well as the study of the properties of colors to create an artistic image in poetry are of particular importance. It should be noted that the study of the use of color in the poetry of poets to some extent reveals the inner world of the artist, provides information about the psychological state of the poet, his inner feelings, emotions and the social environment of that time.

In the works of classical and modern Persian-Tajik poets, different colors were used to ensure the attractiveness of speech, to describe and create unique images.

Colors are one of the most important factors in creating an artistic image, reflecting the theme and content of the work, for example, the seasons and the peculiarities of each of them (white snow in winter, green grass in spring, yellow leaves in autumn). is a tool. From the colors shown in the artistic image, it can be seen that it is autumn, winter or spring. This descriptive property of color can be used in the depiction of inanimate nature and its elements, images and sculptures, as well as in other landscapes and themes. Color, both outwardly and as a metaphor, expresses the deep and inner meaning of a work and its components. For example, the use of colors in the works of many artists created within religious, symbolic, and mythological themes served as a visual and allegorical factor.

The use of color reveals the inner feeling, beauty and appearance of the creative effect. Thus, the creation of qualities such as joy and sorrow, heat and cold, beauty and ugliness, deceit, good and evil, charm, joy and so on, is often related to colors. We can say that in addition to human influence on colors, colors can also affect human life. Colors play an important role in both nature and human life. They are different: black and white, red and blue, yellow and purple and so on. But in the description of the creators, these colors, along with their apparent meanings, reflect psychological meanings in relation to human behavior and ethics, which are a reflection or revelation of the original existence of humanity. Colors have unique properties, and when we mix them, they have a different meaning, but their existence becomes more complex and difficult to understand. This difficulty is not really a bad factor, it depends on the product of the human mind. Colors are an expression of human spirituality and represent the state and mood of the artistic image in the works. For example, the depiction of people's depression, weakness, loneliness in colors increases the effectiveness of works of art.

It should be noted that colors have a profound and significant effect on people's thoughts. Art and fine arts have a special place in the traditions and their interrelationships. Therefore, a number of qualities such as joy and sorrow, warmth and coldness, beauty and ugliness, attractiveness, fatigue, and so on, are always expressed in colors.

From ancient times to the present day, the choice of a particular color has been one of the main features of groups and parties in the formation of political and historical processes. This is evidenced by the emergence of organizations under the names of "black-clad", "white-clad", "red-clad". The dress styles of different ethnic groups also vary depending on their cultural environment and lifestyle. The use of different colors in the play is chosen based on psychological influence, religious ceremonies and national values, social and political conditions.

For example, the book Farhangi Musulmonon (Muslim Culture) says:

"Arabs wear yellow or red to show their anger, and in revenge they wear black turbans and black shoes." 1 Another example of black is related to the successive defeats of these non-Iranian ethnic Iranians. For the Iranians, defeat was a form of disorder and mental exhaustion, and is considered one of the factors in the spread of mysticism

${ }^{1}$ Abulqasim Firdavsi. Shohnoma. Volume IV. Dushanbe: Adib, 2007. p.203 
in these countries. Sufis used to wear a garment called a hirqa. The Sufi's hijab was blue. As for the choice of blue, there is an opinion that the ancient people "blue and black have long been in the spotlight of the Persians, and they wore clothes that have that color." It is also customary for mourners to wear black in mourning, and on the other hand, black is widely used to embody poetic images. For example, Mawlana Rumi in his work "Masnavii ma'navi" described the sadness and depression of people in black:

Gar qazo po`shad siyah hamchun shabat,

Ham qazo dastat bigirad oqibat. ${ }^{2}$

Translation: death will be in a black shirt, and one day he will follow you.

In these verses, the poet uses the art of allegory, and expresses the fact that the deceased wears a black shirt mourning, mourning and mourning.

Black is often used by artists to describe the beauty of their lovers, their beauty, their twinkling eyes, their eyelashes and their dark complexion.

For example:

\section{Translation:}

Ey oftobi oina andar jamoli tu,

Mushki siyoh, mija bar gardan xoli tu. ${ }^{3}$

O mirror sun of your beauty,

It's black musk, your neck brace.

In this verse, the poet uses the art of allegory, likening the beauty of the lover to the sun. He depicts his eyebrows, eyes and cheeks in black.

The poet, like children, loves colors and "plays" with them, first wanting to create an image through them and then to arouse interest in the hearts of readers. Therefore, the world of poetry has its own unique form from different forms. The process of a thorough study of a work of art shows that the analysis of the use of colors, their content and properties in a work of art is closely linked with the in-depth study of the art of artistic text. Therefore, in the works of poets, colors make a significant contribution to the expression of the highest qualities of human emotions, and since ancient times, the use of colors in their place has led to the creation of meaningful, effective and attractive poetry.

The creation of interesting artistic images of different colors is also popular in the poetry of modern Tajik literature. Our poets turned to colors to showcase their high taste and unique art. For example, in the poetry of the poetess Farzona we can see sparks of different colors:

"Az siyohii jahon xudro burun giru biyo,

Translation:

Olame doram zi rangi sabzu, nilivu, gulob" .4

Dunyo zulmatidan chiqib kel,

Menda yashil, ko'k va pushti dunyo bordir. "

The color pink has the meanings of love, devotion, vitality in the artistic expressions "pink connection", "pink dreams" and "pink shirt":

...Pirohani gulob, ya`ne chi?

Ya`ne du bora dil ba jahon dodan

Ya`ne du bora bo havasihufta oshti kardan,

Ya`ne nigohi tahzadaro dar ofoq

dilbarona gusturdan

va raftan

Translation:

ba peshvozi sapedaho, ro`shaniho, taronaho...

... What is a pink shirt?

That is to return to the world to give heart

That is, to reconcile with the desire to live again,

Wide hearts

I have to go towards light, rays, songs. ${ }^{5}$

Or in the third volume of his Qatrae az Muliyon ("A Drop from Muliyon"), in the epic "Bohonai sabz" ("Green excuse"), the poet uses green to create the image of a "sweet green rose". In general, the interest in colors plays an important role in Farzonai Khojandi's poetry. According to literary critic Sarafroz Yunusov, one of the reasons for the joy and happiness in the poetry of this poet is the use of this color in images. S. Yunusov writes in his book "Az zohiri ashyo ba asli haqyatho" ("From the emergence of being to the essence of truth"): Farzona in her book "Payyomi niyogon" used color as a means of poetic pleasure. The color in these poems has a unique and clear meaning

\footnotetext{
2 J. Rumi "Masnavii ma'naviy" Book 1 https://www.sattor.com/jrumi.html/. Page 790

${ }^{3}$ Abulqasim Firdavsi. Shohnoma. Volume IV. Dushanbe: Adib, 2007. p.336

${ }^{4}$ Farzona. Qatrae az Muliyon. Khojand: Nuri Khojand, Volume 1, 2003. Page 453

${ }^{5}$ Farzona. Me`roji shabnam. Dushanbe: Adib, 2006. p.77
} 
and is one of the highest pillars of image creation. In Shaboxuni Bark, we focused on the color green. From an aesthetic point of view, Farzona (life) has "green color", "green smile and green heart", "green happiness" and lives in a green space. We have analyzed this in the poem "O man" which refers to man, and we consider it necessary to state another point:

Fardo tu meguzori bahore faro rasad,

Bo rangi sabzu xandai sabzu kanori sabz.

Fardo tu meguzori, ki xokii digare

Translation:

Bo baxti sabz oramad andar diyori sabz.

Translation:

Tomorrow, as you pass, another spring will come,

In green, in a green smile and in a green heart.

Tomorrow is a different soil as you cross

Lives on a green land with green happiness.

In another poem, Farzona uses the synonyms "nil" and "nilobi" along with green:

Hech medoni, ki rangi orzuhoi dili man ham gulobiand,

Man turo dar orzuhoi gulobiam hame nozam,

Man turo dar orzuhoi gulobiam

Ba shabnamhovu bo xurshedhovu subhho

Payvand mesozam...

You know, the colors of dreams in my heart are pink,

I see you in my pink dreams,

I see you in my pink dreams

To the dew, the sun, and the dawn

I think ...

Color is one of the most effective factors in the creation of images in Farzona's imagination:

Man ki daraxti shabam, mevai moham bideh,

V-ar shafaqog`ushtaam, bo`yi saboham bideh.

Ravshaniyamro bubin, aynaki shomi bikun,

Translation:

Tiragiyamro nigar, rangi rafoham bideh...

I am the tree of the night, give the fruit of the moon,

In my morning kiss, give me the morning breeze.

Look at my light, wear evening glasses,

Look at my dullness, give me a comfortable color ...

In the following epic "White and Black" ("White and Black") the content of the poem is expressed in color:

Dunyo ajib safedu siyoh ast

Ohista mechakad

Bo ashki abr surmai chashmoni osmon.

Oh, ey daraxtho,

Vaqti namozi shom shud, boyad fuzo` girift

Translation:

Bo barfi avvalini zimiston. ${ }^{6}$

The world is strangely black and white

It pours slowly

Clouds of tears flowing in the sky.

Oh, the trees!

It is time for the evening prayer

With the first snow of winter."

As we can see, the poet not only uses colors, but also puts things side by side with things that have contrasting colors in them, and a sense of color emerges by imagining them in the mind of the reader.

Colors are not important in the poems of all poets, for example, the use of colors in the poems of the great Tajik poets Bazar Sabir and Loyik is not obvious. In their poems, love and a view of nature are described high and clear. Creating an artistic image using colors is common in the poetry of modern poets.

In the poem of Dorothy the Savior, color appears as an artistic image in the form of allegory and irony:

Man,

sabzmaste budam

gulobitob,

ki g`urubi xurshedii Avasto

mesabzid

\footnotetext{
${ }^{6}$ S. Yunusov. Khojand, 1997, p. 32
} 


\section{Translation:}

$$
\text { dar nilufarii nigohi armonam... }{ }^{7}
$$

I,

I was green

gulabitob,

was growing

avasto at sunset

in the eyes of my dream ...

The Silver Sunnat's "Poem of the Sun" describes the colors of the rainbow:

Raftam payi andeshahoi gulobiash,

Ranginkamone bud

She'ri oftob

Translation:

Dar varaqi sapedi abr.

I followed his pink thoughts,

It was a rainbow

A poem of the sun

On white cloud pages.

Thus, the use of different colors to create delicate, unique images and colorful landscapes continues in today's literature. The fact that they appear in the poetry of poets with new content, new images testifies to the passion of the authors of the poems.

Colors, which are an integral part of nature, have an impact on various moments of human life and are associated with a number of disciplines, including philosophy, psychology, medicine, history, culture, literature and art. Literature, especially poetry, has risen spiritually from this diversity. Colors appear in different forms, in the creative imagination, and poets have used it to create a unique poetic style and to identify and explain the connections between the components of a poetic image.

From the results of the study of the peculiarities of the use of color elements in poetry, it became clear that colors are used in the poetry of poets in two forms:

1. As a "word" - one of the smallest parts of the text, its understanding plays an important role in understanding the main content of the poem.

2.As the name of a psychological element that helps to better understand the worldview and poetic world of the poet.

According to psychologists, a person's mental, social, political and spiritual abilities can be determined by the type of color he uses.

Also, the use of colors is directly related to a person's mood and mood, and serves to understand their inner world and psyche.

As a result of these studies, we can conclude that the use of colors in the poetry of poets reflects our views on the personality of the poet and the socio-political environment in which he lived.

\section{REFERENCES:}

1. Abulqosim Firdavsiy. Shohnoma. IV jild. Dushanbe: Adib, 2007

2. Farzona. Qatrae az Muliyon. Xo“jand: "Nuri Xo“jand”, 1-jild,2003

3. Farzona. Me`roji shabnam. Dushanbe: Adib , 2006

4. S. Yunusov. "Az zohiri ashyo ba asli haqiqatho" Xo'jand, 1997

5. D. Najot. Mahtobe xamida dar ruqo'. - Dushanbe: Adib, 2006

6. Gulruxsor. "Devoni ishqu, ashku, xanda" Pajo'hishgohi farhangi forsu tojik: 2006

7. J. Rumiy "Masnavii ma'naviy" 1-daftar https://www.sattor.com/jrumi.html/

${ }^{7}$ D. Najot. Mahtobe hamida dar ruqa '. - Dushanbe: Adib, 2006. p.232 